\section{HOSPITAL OPINION.}

[Oontributions critical, snggestive, controversial, and technical are in vited for this column, which is open to everyone who has anythinig to gay that is of practicalvalue and interest.]

\section{THE YROPOSED CENTRAL HOSPITALS BOARD} FOR LONDON.

A paragraph, which appears in your issue of 22nd inst., under the heading of "Notes and News," states that "a minority of the hospital secretaries are, we understand, actively fermenting a strenuous opposition to the proposed Central Hospitals Board. It is reported that a meeting of these gentlemen has been held at the Royal Free Hospital."

This paragraph is so entirely incorrect and misleading that I desire to correct it by a statement of the facts respecting the meetin $r$ referred to.

Being desirous of ascertaining what were the opinions of some of $\mathrm{my}$ brother officials on the subject of the proposed Central Board, I invited about thirty hospital secretaries to a social gathering, for the purpose of affording an opportunity for an informal conversation on this question, which is of paramount importance to all who are engaged in hospital work. It was distinctly understcod that we met solely for interchange of views, and that no resolutions would be brought forward. Whatever may have tbeen the opinions expressed by others, I may venture to state that, speaking as a private individual and not as representing any institution, I am personally not averse to some kind of central board, although I am not uble to approve the schemes which have already been brought forward. I am, yours faithfully,

Royal Free Hospital, Gray's Inn Road, W.C. CoNRAD W. THIES. April 24th, 1893

* * We publish this lettar with pleasure, although it does not controvert in any way the statement that " a minority of the hospital secretaries are fermenting a strenuous opposition to the proposed Hospitals Board." It is important that this statement should be definitely confirmed or refuted. Besides, Mr. Thies only states his own views, without in any way denying that the majority of the speakers at the meeting in question were hostile to the formation of a Central Hospitals Board for London. - ED. T. $H$.

\section{CONSTRUCTION NOTES.}

Frve hundred pounds has been recoived by the Committee of the Glasgow Samaritan Hospital for Women towards the capital account of the trustees of the Bellahouston Fund. It has been decided to erect a hospital to provide accommodation for from twenty: the Victoria Baths.

The Manchester Sodthern and Maternity Hospital. Mr. John Ely, F.R.I.B.A., of Manchester, has designed these new buildings, which are to be erected on a site in Oxford.road, and facing the Whitworth Park, granted free of cost, save a low chief rent, by the Council of Owens College. The cost is estimated at about $£ 12,000$. The administrative block will face Oxford Road, and will be built of red brick and terra-cotta.

Is the annual report of the Committee of the Hounslow Hospital, it was stated that it is decided to build a new ward forbhwith, to be called the "Heston" Ward, in compliance with injunctions from the late Mr. W. Taylor, who contriwuth $£ 500$ for the erection of the same. Two additional bedrooms for the medical staff are also to be added. The whole of the sanitary arrangements are to be altered and improved, and the ventilation of the wards will be rendered more satisfactory.

THE proposed hospital for infectious diseases at Stroud is to be planned by Mr. Milnes, who estimates that the cost of the building will be $£ 4,000$, exclusive of the cost of site and of the furniture. The hospital, the construction of which is to be proceeded with forthwith, is to be erected of brick, stone, and slate, and will consist of four blocks, i.e., one administrative and three diseases blocks, to accommodate thirty-six patients (each ward containing two wards of six beds each), of which one block is to be reserved for small. pox. A piece of land will be purchased immediately adjoining the site chosen for the hospital for the purpose of isolation of the same, which aite is on the north-east corner of the land at the workhouse belonging to the Stroud Union.

\section{FESTIVAL DINNERS.}

\section{THE NORTH LONDON HOSPITAL FOR}

\section{CONSUMPTION.}

Mr. H. L. W. Lawson, M.P., presided at the annual festival of this charity at the Whitehall Rooms, Hotel Metropole. Amongst those present were Mr. A. Hoare (treasurer), Mr. J. D. Alcroft, Mr. C. Tyler, Colonel A. M. Arthur, the Rev. H. Hughes, Mr. J. S. Fletcher, the Rev. A. Godson, Dr. F. Weaver, Mr. W. F. Malcolm, Mr. T. F. Downes, Mr. H.C. Burdett, Dr. F. R. Walters, Dr. Dougles Pidcock, Dr. J. E. Squire, Dr. Watson, Mr, C. E. Graseman, Dr. Danford Thomas, Dr. Bernard Dyer, the Rev. T. Turner, Dr. Forbes Winslow, and Mr. L. H. Hill (secretary). The Chairman proposed the toast of the evening, "Prosperity to the North London Hospital for Consumption and Diseases of the Chest." He said they were there to aid in fighting the saddest and surest of all the diseases that affict humanity, and he was glad to say that he had received many letters from various parts of the country expressing sympathy with their work. Among others he had received a letter from the late Lord Derby regretting his inability to attend, and referring to a contribution, which he said he hoped would compensate for his absence-one of the last acts of a truly English life being to help the hospital in whose aid they were met that nigho. Lozdon was a place peculiarly favourable to the development of this disease, and he thought he might say that the hospital was in the right place and was conducted on the right lines, and he hoped they would make a special effort this year to support the extension of the work. In response subscriptions were announced to the amount of $£ 1,200$.

\section{SCRAPS AND GLEANings.}

OVEn 12000 ipersons are found employment for in the theatres of cro Metropolis.

Dr. REIDAL, physician to the King of Spain, visita his Royal patient

THERE are 950 miles of telephoneline ketween New York and Ohicxgo; this is the greatest length exiant.

THE authorities of Waltham Abbey have made arrangements to erect an Infections Diseases Hospital.

THE first prize for the best examination to the University cf Ohicago was passed last Ohristmas by a young coloured lady.

THE sife for the proposed infections difeas es hospital at Northam contınues to cause mach discussion among the ratepajers.

A RUSSIAN peasant has just died aged 120 years. Ono of his gons had attaine 1 the age of 92 , ana his father was $130 \mathrm{when}$ he died.

THE electric lighting of the Ohicago Exhibition will hare to be pra vided with 15,000,000 feet of insulated wire in order to distribate the
curreat.

IT is satisfactory to be able to state in the interests of the Swanges Hospital that the financial proceeds of the annual ball recently held
amount to $£ 93$.

THE Swedes $h$ vo a curious method of treating cirnnkards; these offenders are i mprisored forthwith, and durnng their detention are fed
on bread and wire.

THE annual meeting of German Naturalists and Medioal non will bo he'd in Sertomb-r at Nuremberg. The addresses will bo delivered by Professor V. Helmhols.

THE report of the anual meeting of the Horsham Cottage Hospital was a most favourable one. The Committee's report dealt with a period of balance in hand of which no

Protests against the proposed aite, at Oanterbury, of an Infections Diseases Hosp.tal, continue to increase in numbers. The site is objected to as inter ftring with, and virtually. destrosing, one of the most W

We are glad to be able to report that the Duke of Westminster has given $f l 10$ towards the co. $t$ of sending to every clergyman in the kingdom a copy of the first number of "Temporal Welfare," the crgan of the Oha rch of Englazd Sanitary Asscciation,

Vores are urgently needed for George Edward Fergnson, who is a candidate for election. May, 1893 (last chance), at the Royal Mejical Benevolent Oollege, Epsom. Proxies will be thankfully received by Mrs. K. Ferguson, Glendale, Taswell Rosd, Scuthsea.

The Ooventry Provident Disconsary has now 25,000 members. This establishm ent was bailt for the avowed parpose of encouraging thrif ameng the roor; bat it appears that many of the members belong to class who have no right to derive benefits from a provident institntion. THe bazaar beld recent'y in the Eye Infirmary at Sunderland proved a great financial success, os well as enabling visitors to inspet proved buildings, 2200 was added to the tands of the institution. the new receipts from the two days sale, and the existing mortgage was paid off.

The Editor of a Budapest newspaper has given 250,000 florins on the death of his wife, for the foundation of a children's horins on the city. This generous gift comes from one of tte Jewish faith for that few but Jews ever devote sugh sums to parposes of that charita indeed, in Hungary. 